\title{
Epoetin- $\beta$ treatment in patients with cancer chemotherapy- induced anaemia: the impact of initial haemoglobin and target haemoglobin levels on survival, tumour progression and thromboembolic events
}

\author{
M Aapro*,', B Osterwalder, A Scherhag ${ }^{2,3}$ and HU Burger \\ 'Institut Multidisciplinaire d'Oncologie, Clinique de Genolier, I, route du Muids, Genolier, Switzerland; ${ }^{2}$ F Hoffmann-La Roche Ltd, Basel, Switzerland; ${ }^{3}$ st \\ Medical Clinic, University Hospital Mannheim, University of Heidelberg, Mannheim, Germany
}

BACKGROUND: Epoetin- $\beta$ is used to treat patients with cancer undergoing chemotherapy to alleviate the symptoms of anaemia, reduce the risk of blood transfusions and improve quality of life (QoL).

METHODS: This meta-analysis of all 12 randomised, controlled studies of epoetin- $\beta$ evaluated the impact of therapy at different $\mathrm{Hb}$-initiation levels and to different target $\mathrm{Hb}$ levels on overall survival, tumour progression and thromboembolic events (TEE). An analysis of risk factors pre-disposing patients to TEEs under epoetin- $\beta$ therapy was also performed. A total of 2297 patients are included in the analysis.

RESULTS: Analyses based on various Hb-initiation levels indicate no detrimental impact on survival (HR 0.99; 95\% Cl 0.70, I.40) and a favourable impact on disease progression ( $\mathrm{HR} 0.73 ; 95 \% \mathrm{Cl} 0.57,0.94)$ when epoetin- $\beta$ was used within its licensed indication $\left(\mathrm{Hb}\right.$ initiation $\leqslant 10 \mathrm{~g} \mathrm{dl}^{-1}$ ) or the EORTC recommended level of $1 \mathrm{I} \mathrm{g} \mathrm{dl}^{-1}$. An increased risk of TEEs is seen for all Hb-initiation level strata and a detrimental impact on survival is seen when initiating epoetin- $\beta$ therapy at $\mathrm{Hb}$ levels $>$ II g $\mathrm{dl}^{-1}$. We observe no association between high target $\mathrm{Hb}$ levels $\left(\geqslant 13 \mathrm{~g} \mathrm{dl}^{-1}\right)$ and an increased risk of mortality, disease progression or TEEs with epoetin- $\beta$ compared with control.

CONCLUSION: The results of this analysis indicate that epoetin- $\beta$ therapy has no detrimental impact on survival or tumour progression when initiated at $\mathrm{Hb}$ levels up to II $\mathrm{g} \mathrm{dl}^{-1}$. Furthermore, there is no evidence to suggest that high $\mathrm{Hb}$ values achieved during epoetin- $\beta$ therapy are associated with an increased mortality, disease progression or TEE rate.

British Journal of Cancer (2009) I 01, 196I-197I. doi:I0.1038/sj.bjc.6605255 www.bjcancer.com

Published online 29 September 2009

(c) 2009 Cancer Research UK

Keywords: anaemia; epoetin- $\beta$; survival

Anaemia frequently occurs in patients with cancer either as a result of the underlying malignancy or as a consequence of myelosuppressive chemotherapy or radiotherapy, or due to a combination of both (Bokemeyer et al, 2005). The symptoms of anaemia have a significant impact on a patient's condition and QoL (Ludwig et al, 2004) and as an independent prognostic factor, anaemia is associated with adverse outcomes in patients with a variety of malignancies (Caro et al, 2001).

Erythropoiesis-stimulating agents (ESAs) increase Hb levels and reduce transfusion requirements in patients with cancer (Littlewood et al, 2001; Österborg et al, 2002; Vansteenkiste et al, 2002). In addition, improvement in patients' QoL when compared with placebo or standard transfusion therapy was also shown following

*Correspondence: Dr M Aapro, Institut Multidisciplinaire d'Oncologie, Clinique de Genolier, I, route du Muids, Genolier CH- I272, Switzerland; E-mail: maapro@genolier.net

Received 9 March 2009; revised 14 July 2009; accepted 21 July 2009; published online 29 September 2009
ESA therapy (Littlewood et al, 2001; Crawford et al, 2002; Boogaerts et al, 2003).

Pre-clinical data have suggested an enhanced tumour response and delayed tumour progression associated with ESA treatment (Mittelman et al, 2001; Thews et al, 2001; Stuben et al, 2003). Moreover, in clinical studies, a potential survival benefit has been shown in patients undergoing cancer therapy who received treatment with ESAs (Antonadou et al, 2001; Glaser et al, 2001; Littlewood et al, 2001). The first of two meta-analyses of controlled trials in cancer patients receiving ESAs, reported by the Cochrane Group, showed a trend toward increased survival in patients treated with ESAs and supported these findings (Bohlius et al, 2005). In the second meta-analysis (57 trials including 9353 patients), however, a shift of the hazard ratio for survival towards an increased risk for patients receiving various ESAs was shown (Bohlius et al, 2006, 2008).

An association between erythropoietin treatment and increased mortality was originally suggested by two studies in cancer patients (Henke et al, 2003; Leyland-Jones et al, 2005) raising concerns about the safety of ESAs when targeting high Hb levels 
(12-14 $\mathrm{g} \mathrm{dl}^{-1}$ or higher) (Luksenburg et al, 2004). In addition, three studies reporting a detrimental impact of ESA treatment on survival have recently been published (Overgaard et al, 2007; Wright et al, 2007; Smith et al, 2008), although one of these studies (Overgaard et al, 2007) remains to be reported in full. Methodological limitations of the clinical studies aimed at maintaining a high $\mathrm{Hb}$ level in cancer patients (Henke et al, 2003; Leyland-Jones et al, 2005), may have confounded the results and influenced the findings (Leyland-Jones and Mahmud, 2004; Vaupel and Mayer, 2004). Studies evaluating different haematocrit levels in end-stage renal failure patients with cardiovascular risk factors (Besarab et al, 1998; Luksenburg et al, 2004) have suggested that increased mortality may be because of a higher risk of thromboembolic events (TEEs) under ESA therapy. Hypotheses that ESAs may promote tumour growth through erythropoietin receptor activation, stimulation of angiogenesis or through hypoxia improvement through $\mathrm{Hb}$ increases have also been proposed (Kelleher et al, 1998; Acs et al, 2001, 2002; Arcasoy et al, 2002; Yasuda et al, 2003; Janecka, 2004; Vaupel and Mayer, 2004).

We previously reported results of an updated meta-analysis of 12 randomised, controlled studies of epoetin- $\beta$ conducted in 2301 patients undergoing cancer therapy (Aapro et al, 2008a) including three recently completed trials with longer term follow-up in patients with head and neck cancer (Henke et al, 2003), patients with metastatic breast cancer (Aapro et al, 2008b) and patients with cervical cancer (Strauss et al, 2008). The results of this metaanalysis based on individual patient level data showed no statistically significant difference between patients receiving epoetin- $\beta$ or control (standard treatment) in terms of overall survival, a favourable trend with respect to the risk of disease progression for patients receiving epoetin- $\beta$ and a higher risk of thromboembolic events associated with epoetin- $\beta$ treatment (Aapro et al, 2008a). Recently, the Cochrane Collaboration has published an updated meta-analysis, which includes data on epoetin- $\alpha$, epoetin- $\beta$ and darbepoetin from 53 randomized, controlled studies in cancer patients. The data from this updated meta analysis, suggested a negative effect on overall survival in the overall study population, however, in those patients receiving cancer chemotherapy, no significant adverse effects on overall survival were observed (Bohlius et al, 2009).

As a consequence of the safety concerns raised by some studies, the European Health Authorities requested the product labels for marketed ESAs to be restricted to a Hb-initiation level $<10 \mathrm{~g} \mathrm{dl}^{-1}$ and a $\mathrm{Hb}$ target not to exceed $12 \mathrm{~g} \mathrm{dl}^{-1}$. Furthermore, the European Health Authorities have stated that transfusions should be seen as the preferred option. The updated EORTC treatment guidelines, however, recommend the initiation of ESA therapy at $\mathrm{Hb}$ levels of between 9 and $11 \mathrm{~g} \mathrm{dl}^{-1}$ and a sustained $\mathrm{Hb}$ level of $\sim 12 \mathrm{~g} \mathrm{dl}^{-1}$ should be the target for treatment with ESAs (Bokemeyer et al, 2007; Aapro and Link, 2008). Below a Hb level of $9 \mathrm{~g} \mathrm{dl}^{-1}$, blood transfusions followed by ESA treatment should be considered and prophylactic use of erythropoietins in subjects with normal $\mathrm{Hb}$ levels scheduled to undergo chemotherapy or radiotherapy is not recommended.

The objectives of this analysis are to evaluate the impact on overall survival, disease progression and TEEs of different $\mathrm{Hb}$ intervention and target levels for epoetin- $\beta$ therapy and in particular, to explore the safety of epoetin- $\beta$ with respect to its effects on overall survival and disease progressions when used within the $\mathrm{Hb}$ intervention and target levels as recommended in the revised European label. These data have not been reported as yet and are considered of considerable relevance for prescribing physicians. Furthermore, the influence of baseline prognostic factors on the observed epoetin- $\beta$ effect with respect to time to thromboembolic event in the pooled patient population $(N=2301)$ from 12 controlled epoetin- $\beta$ trials in cancer patients was assessed.

\section{MATERIALS AND METHODS}

Data presented in this article are derived from an updated metaanalysis of 12 controlled studies designed to evaluate differences between epoetin- $\beta$ and control (placebo or standard care) with regard to overall survival, disease progression and TEEs during and up to 28 days after end of therapy with epoetin- $\beta$.

Eligible studies included all randomised, controlled studies of epoetin- $\beta$ conducted by the drug sponsor (F Hoffmann-La Roche (Basel, Switzerland) or Boehringer Mannheim) in patients with cancer undergoing treatment (chemotherapy (seven studies), surgery (two studies), radiotherapy (two studies) or radio-chemotherapy (1 study)). The meta-analysis is based on data derived at the individual patient level. Individual study details are summarised in Table 1.

As most of the studies were originally designed to evaluate the efficacy of epoetin- $\beta$ with respect to anaemia correction, in the majority there was no follow-up for survival or tumour progression beyond study treatment plus a standard 28-day period used to assess SAEs, deaths and disease progression. Furthermore, tumour status was not prospectively assessed in many of the earlier trials with short-term follow-up and details of disease progression were routinely reported as adverse events. For the meta-analysis, this information was analysed retrospectively by reviewers blinded to treatment assignment. Four of the studies, which did evaluate the effects of epoetin- $\beta$ on survival and/or disease progression (Henke et al, 2003; Österborg et al, 2005; Aapro et al, 2008b) or response to treatment (Strauss et al, 2008) provided long-term (up to 60 months) follow-up information for overall survival or tumour progression. For the assessment of TEEs, all reported adverse events were reviewed against a pre-specified list of TEEs, which was applied consistently across all studies.

\section{Statistical analyses}

Overall survival, time to progression and time to TEE were analysed by Kaplan-Meier estimates in which the data were stratified; (1) by $\mathrm{Hb}$ intervention level (baseline $\mathrm{Hb}$ level), and (2) by maximum $\mathrm{Hb}$ level achieved up to 28 days after end of treatment (target Hb level).

Two sets of analyses were performed. One set of analyses included individual patient data from all 12 studies. For these analyses, patients without events were censored at 4 weeks after the last entry in the administration record. A second set of analyses using only pooled patient data from the studies with long-term follow up in which all events were included in the analysis was performed for overall survival (Henke et al, 2003; Österborg et al, 2005; Strauss et al, 2008; Aapro et al, 2008b) and time to progression (Henke et al, 2003; Strauss et al, 2008; Aapro et al, $2008 \mathrm{~b})$. In the study by Österborg et al, 2005, patients were followed for survival but not for disease progression, therefore this study was excluded from the time to progression analyses. Patients without an event were censored at the time of last follow-up or, if no follow-up information was available, 4 weeks after the last entry in the administration record. Overall analyses were performed, unstratified as well as stratified by the study.

Risk factors for TEEs and their influence on the observed epoetin treatment effect were also investigated. Potential risk factors were defined at baseline and, as a first step, univariate models estimated the effect of the prognostic factor as well as a corrected treatment effect. Factors that were statistically significant in the univariate model or showed a trend at an $\alpha$-level of $15 \%$ were then selected and patients classified into risk subgroups based on clinically established risk profiles. The impact of these selected factors on time to TEE was then analyzed in Cox regression models adjusting by subgroup for each factor separately, for subgroups of patients with no risk factors, one, two and three or more risk factors at baseline to investigate whether a potential risk for TEE in combination with epoetin- $\beta$ 
Table I Main features of randomised clinical trials of epoetin- $\beta$ in patients with cancer

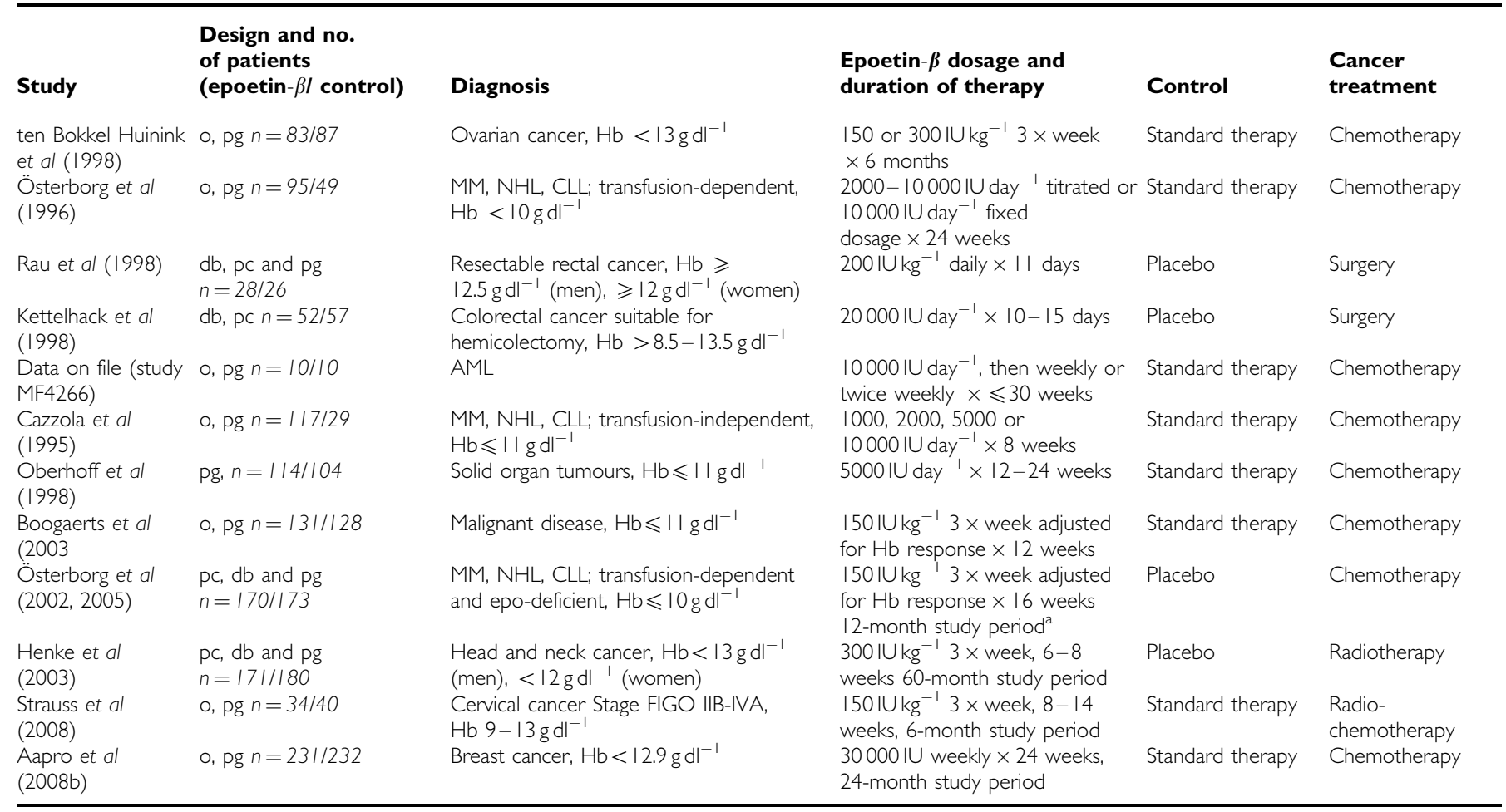

Abbreviations: $\mathrm{AML}=$ acute myeloid leukaemia; $\mathrm{CLL}=$ chronic lymphocytic leukaemia; $\mathrm{db}=$ double-blind; $\mathrm{Hb}=$ haemoglobin; $\mathrm{MM}=$ multiple myeloma; $\mathrm{NHL}=$ non-Hodgkin's lymphoma; $\mathrm{o}=$ open design; $\mathrm{pc}=$ placebo controlled; $\mathrm{pg}=$ parallel group. Patients had anaemia unless stated otherwise, and standard therapy consisted of antitumour treatment

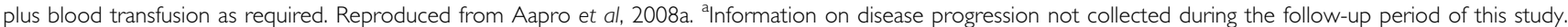

treatment was attributable to a particular subgroup of patients at specific risk.

\section{RESULTS}

\section{Analysis populations}

The 12 randomized, controlled trials enrolled a total of 2301 patients of whom 2297 (epoetin- $\beta, n=1244$; control, $n=1053$ ) were included in the analysis; four patients were excluded because of not receiving treatment of any kind during the trials. In the studies, three patients in the epoetin group received no epoetin- $\beta$ and five patients randomised to control received epoetin- $\beta$. Patients were analysed according to the treatment received.

\section{Baseline characteristics and follow-up}

Baseline characteristics of the patients in the analysis are described in the earlier publication (Aapro et al, 2008a) and are shown in Table 2. Of the 2297 patients in the analysis, $35 \%$ had non-myeloid haematological malignancies (mainly non-Hodgkin's lymphoma or multiple myeloma) and 65\% had solid tumours (most commonly primary malignancies of the breast, head and neck, colon/rectum and ovary). Other than the slightly higher proportion of patients in the epoetin group with ovarian carcinoma as a result of the three arm design of the study by ten Bokkel Huinink et al (1998), no clinically relevant differences between the groups were noted.

Median initial weekly epoetin- $\beta$ dose was 27000 IU (range 0 -90 $000 \mathrm{IU}$ ). Mean baseline $\mathrm{Hb}$ level was $10.6 \mathrm{~g} \mathrm{dl}^{-1}$ in the control arm and $10.5 \mathrm{~g} \mathrm{dl}^{-1}$ in the epoetin- $\beta$ arm. During treatment, mean maximum $\mathrm{Hb}$ level was $13.4 \mathrm{~g} \mathrm{dl}^{-1}$ in the epoetin- $\beta$ arm and $12.0 \mathrm{~g} \mathrm{dl}^{-1}$ in the control arm. The mean baseline adjusted $\mathrm{Hb}$ area under the curve was $1.24 \mathrm{~g} \mathrm{dl}^{-1}$ with epoetin- $\beta$ compared with $0.07 \mathrm{~g} \mathrm{dl}^{-1}$ with control.

Duration of follow up across the 12 studies was comparable in the epoetin- $\beta$ (median 3.9 months) and control (median 3.8 months) treatment groups (patients without events from the four studies with long-term follow up were censored 4 weeks after last entry in the administration record). In the four studies with longterm follow-up data, when all events were included, median follow up was also comparable (28.8 months with epoetin- $\beta$ and 29.8 months with control) (Aapro et al, 2008a).

\section{Impact of baseline $\mathrm{Hb}$ level on overall survival}

As previously described in Aapro et al (2008a), there was no statistically significant difference between patients receiving epoetin- $\beta$ or control (standard treatment) in terms of overall survival in the unstratified pooled analysis of all 12 controlled studies (HR of $1.13,95 \%$ CI $0.87 ; 1.46, \log$-rank $P$-value $=0.355$, $N=2297)$. Comparable results were found in the unstratified pooled analysis of the four studies with long-term follow up (HR of 1.13 (95\% CI 0.98; 1.31, log-rank $P$-value $=0.082, N=1227$ ).

When stratified by baseline $\mathrm{Hb}$ level, the time to event analyses in patients with baseline $\mathrm{Hb}$ levels $\leqslant 10 \mathrm{~g} \mathrm{dl}^{-1}$ showed a HR of 0.99 (95\% CI 0.70; 1.40; log-rank $P$-value $=0.96 ; N=950$ ) (Figures $1 \mathrm{~A}$ and $2 \mathrm{~A}$ ) and for patients with baseline $\mathrm{Hb}$ levels $\leqslant 11 \mathrm{~g} \mathrm{dl}^{-1}$ a HR of 1.09 (95\% CI $0.80 ; 1.47 ; N=1426)$ (Figure 2A). These results are within the range of those for the unstratified pooled population. However, for patients whose baseline $\mathrm{Hb}$ levels were above $11 \mathrm{~g} \mathrm{dl}^{-1}$, the mortality risk appeared to be higher (HR of 1.25, $95 \%$ CI $0.75 ; 2.07 ; N=865$ ) (Figure $2 \mathrm{~A}$ ).

Comparable results were found in the pooled analysis of four studies with long-term follow up (Table 3). These data suggest no increased risk of epoetin- $\beta$ treatment on overall survival in 
Table 2 Baseline characteristics of pooled study populations

\begin{tabular}{|c|c|c|}
\hline Parameter & $\begin{array}{c}\text { Control } \\
(n=1053)\end{array}$ & $\begin{array}{l}\text { Epoetin- } \beta \\
(n=\mid 244)\end{array}$ \\
\hline Gender (Percentage of male/female) & $37 / 63$ & $38 / 62$ \\
\hline \multicolumn{3}{|l|}{ Race } \\
\hline$n$ & 921 & 1069 \\
\hline Caucasian & $882(96 \%)$ & $1029(96 \%)$ \\
\hline Other & $39(4 \%)$ & $40(4 \%)$ \\
\hline Mean age in years (range) & $58.8(|9-9|)$ & $59.3(20-87)$ \\
\hline Mean weight in kg (range) & $67.7(30.0-131.5)$ & $67.1(35.0-118.0)$ \\
\hline n & 1048 & 1235 \\
\hline Mean height in cm (range) & | $66.7(\mid 40-198)$ & $166.4(126-198)$ \\
\hline n & 809 & 1012 \\
\hline \multicolumn{3}{|l|}{ Tumour type, n (\%) } \\
\hline Haematological & $331(31.4)$ & $465(37.4)$ \\
\hline Acute myeloid leukaemia & $10(3.0)$ & $10(2.2)$ \\
\hline Multiple myeloma & $125(37.8)$ & $204(43.9)$ \\
\hline Non-Hodgkin's lymphoma & $195(58.9)$ & $247(53.1)$ \\
\hline Hodgkin's lymphoma & $1(<1)$ & $4(<1)$ \\
\hline Solid & $722(68.6)$ & $779(62.6)$ \\
\hline Breast & $261(36.2)$ & $261(33.5)$ \\
\hline Head/neck & $174(24.1)$ & $181(23.2)$ \\
\hline Gynaecological & $133(18.4)$ & $186(23.9)$ \\
\hline Gastrointestinal & $96(13.3)$ & $100(12.8)$ \\
\hline Other & $58(8.0)$ & $51(6.6)$ \\
\hline \multicolumn{3}{|l|}{ Haemoglobin } \\
\hline$n$ & 1050 & $124 \mid$ \\
\hline Mean (range) & $10.6(5.7-16.7)$ & $10.5(4.2-17.1)$ \\
\hline Median & 10.5 & 10.4 \\
\hline
\end{tabular}

Data were collected from all 2297 patients unless otherwise stated. Reproduced from Aapro et al, 2008a.

patients whose baseline haemoglobin was $\leqslant 10 \mathrm{~g} \mathrm{dl}^{-1}(\mathrm{HR}=0.91$, $95 \%$ CI $0.72 ; 1.16)$ or $\leqslant 11 \mathrm{~g} \mathrm{dl}^{-1}(\mathrm{HR}=1.03,95 \%$ CI $0.85 ; 1.25)$, which was consistent with the unstratified analysis $(\mathrm{HR}=1.13$, $95 \%$ CI $0.98 ; 1.31$, log-rank $P$-value $=0.082)$. In patients whose baseline haemoglobin levels were above $11 \mathrm{~g} \mathrm{dl}^{-1}$, however, the risk of mortality appeared to increase $(\mathrm{HR}=1.24,95 \% \mathrm{CI} 1.00 ; 1.53)$.

\section{Impact of baseline $\mathrm{Hb}$ levels on disease progression}

In the unstratified pooled analysis of 12 controlled studies, no significant differences between the epoetin- $\beta$ and control groups were seen in the number of patients with disease progression (Aapro et al, 2008a). Kaplan-Meier analysis indicated a reduced risk of progression for patients treated with epoetin $\beta$ compared with control $(\mathrm{HR}=0.85, \quad 95 \% \quad \mathrm{CI} \quad 0.72 ; 1.01, \quad$ log-rank $P$-value $=0.072$ ).

When stratified by baseline $\mathrm{Hb}$ level, the subgroup with a baseline $\mathrm{Hb}$ level $\leqslant 10 \mathrm{~g} \mathrm{dl}^{-1}$ had a relative risk reduction for disease progression of $27 \%$ (HR $0.73,95 \%$ CI 0.57 ; 0.94; log-rank $P$-value $=0.013 ; N=950$ ) (Figures $1 \mathrm{~B}$ and $2 \mathrm{~B}$ ) and the subgroup with a baseline $\mathrm{Hb}$ level $\leqslant 11 \mathrm{~g} \mathrm{dl}^{-1}$ had a relative risk reduction for disease progression of $20.0 \%$ (HR $0.80,95 \%$ CI $0.65 ; 0.99$; $N=1426$ ) with epoetin- $\beta$ compared with control (Figure 2B). These results are consistent with the results for the pooled population (relative risk reduction of $15 \%$ ). For patients with baseline $\mathrm{Hb}$ values $>11 \mathrm{~g} \mathrm{dl}^{-1}$, there was no evidence of an increased risk of disease progression associated with epoetin- $\beta$ treatment (HR 0.95, 95\% CI 0.70; 1.28) (Figure 2B).

In the three studies with long-term follow up of disease progression, results suggested favourable effects of epoetin- $\beta$ over control with respect to disease progression in the subgroups with a baseline $\mathrm{Hb}$ level $\leqslant 10 \mathrm{~g} \mathrm{dl}^{-1}(\mathrm{HR}=0.59,95 \% \mathrm{CI} 0.36 ; 0.96)$ and a baseline $\mathrm{Hb}$ level $\leqslant 11 \mathrm{~g} \mathrm{dl}^{-1} \quad(\mathrm{HR}=0.85,95 \%$ CI $0.64 ; 1.13$; Table 3). This finding contrasts with a $13 \%$ higher risk of disease progression for the unstratified pooled population. For subgroups with baseline $\mathrm{Hb}$ levels $>11 \mathrm{dl}^{-1}$, the relative risk for disease progression with epoetin- $\beta$ increased by $30 \%$ compared with control (Table 3 ).

\section{Impact of baseline $\mathrm{Hb}$ levels on time to TEE}

Across the 12 studies in the unstratified pooled analysis, a higher TEE event rate was observed in the epoetin- $\beta$ group compared with the control ( $0.22 v s 0.14$ events/patient year) with an overall HR for time to TEE of $1.62(95 \%$ CI 1.13; 2.31, log-rank $P$-value $=0.008)$ (Aapro et al, 2008a).

When stratified by baseline $\mathrm{Hb}$ level (Figure 2C) an increased risk of thromboembolic events with epoetin- $\beta$ compared with control was seen across all baseline $\mathrm{Hb}$ strata subgroups; the risk being lowest in patients with baseline $\mathrm{Hb}$ levels $\leqslant 10 \mathrm{~g} \mathrm{dl}^{-1}$ and increasing with the higher the baseline $\mathrm{Hb}$ level.

\section{Impact of maximum-achieved $\mathrm{Hb}$ levels on survival, disease progression and TEEs}

The hazard ratios for overall survival, time to progression and time to TEE stratified by maximum-achieved $\mathrm{Hb}$ level for the pooled population of 12 studies are shown in Figure 3. These data indicate a shift towards an increased mortality risk for subgroups with maximum-achieved $\mathrm{Hb}$ values between 10 and $<13 \mathrm{~g} \mathrm{dl}^{-1}$ (HR range: 1.20-2.60 for overall survival (Figure 3A); 1.11-1.45 for disease progression (Figure $3 \mathrm{~B}$ ); $1.53-5.04$ for time to TEE (Figure 3C)). However, there was no indication for an increased risk of mortality, disease progression or TEEs in patients achieving maximum $\mathrm{Hb}$ levels $>13 \mathrm{~g} \mathrm{dl}^{-1} \quad(\mathrm{HR}=0.79,1.08$ and 1.32, respectively) when compared with the unstratified analyses (Figure 3).

In the pooled analyses of studies with long-term follow up (Table 3), a shift of the hazard ratio towards an increased mortality risk was seen for subgroups with maximum-achieved $\mathrm{Hb}$ values between 10 and $<12 \mathrm{~g} \mathrm{dl}^{-1}$ (HR range 1.71-1.89 for overall survival). However, for subgroups with maximum-achieved $\mathrm{Hb}$ levels $\geqslant 12 \mathrm{~g} \mathrm{dl}^{-1}$ (HR range $1.50-1.59$ ) there was no indication for a further increased risk of mortality.

With regards to disease progression in the three studies with long-term follow up, a shift in the hazard ratios towards an increased risk of progression was seen in all subgroups with maximum-achieved $\mathrm{Hb}$ values of between 10 and $\leqslant 13 \mathrm{~g} \mathrm{dl}^{-1}$. However, there was no indication of an increased risk in the subgroup of patients achieving maximum $\mathrm{Hb}$ levels $>13 \mathrm{~g} \mathrm{dl}^{-1}$ (Table 3).

\section{Risk factors for thromboembolic events}

Risk factors and their influence on the epoetin- $\beta$ treatment effect with respect to TEEs were investigated in a Cox regression model into which treatment and other prognostic factors were added (Table 4). Five factors; previous history of TEEs, previous coronary artery disease, baseline hypertension, baseline dyslipidemia and age at baseline $>65$ years were statistically significant or showed a trend at an $\alpha$-level of $15 \%$ in these univariate models. Adjusted treatment effects remained unchanged. Results of the Cox regression analysis based on the number of risk factors at baseline indicated that the risk of TEEs was generally higher in patients with two or more risk factors compared to those with fewer than two risk factors; Table 4). Overall analyses stratified by study yielded similar results. 
A

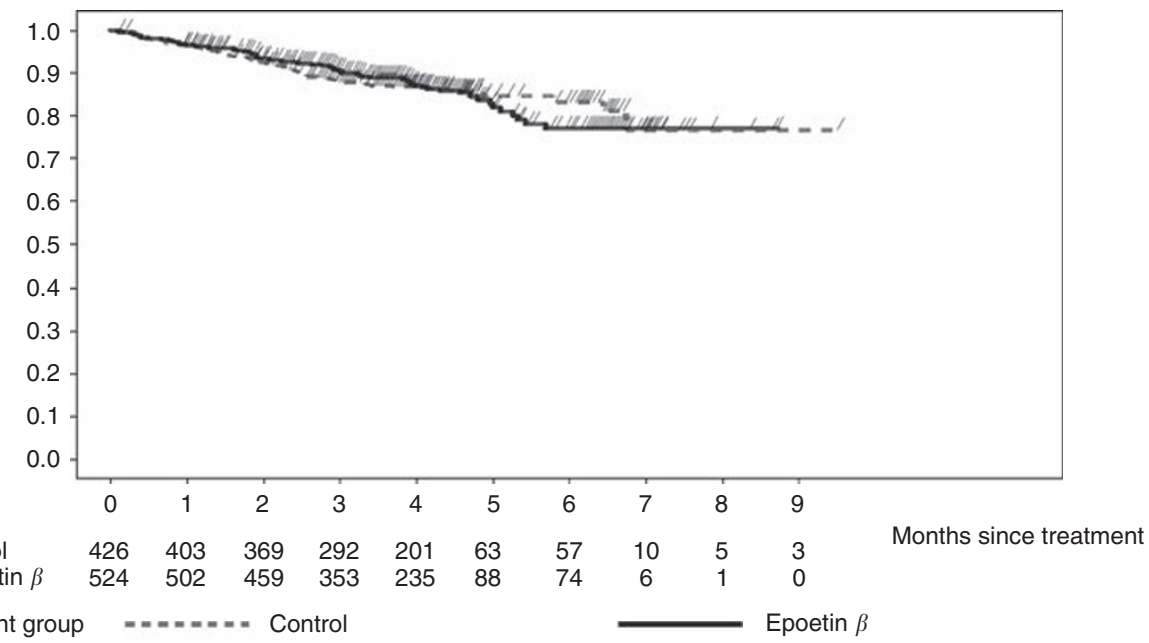

B

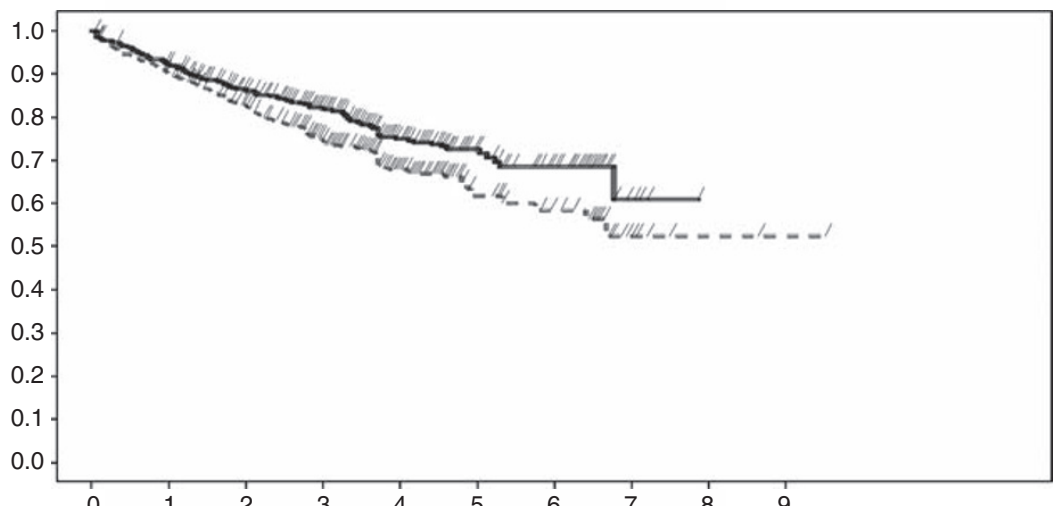

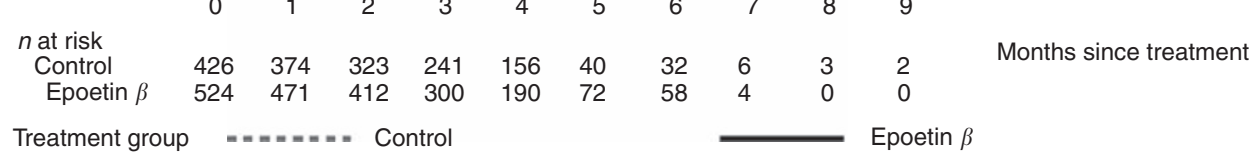

Figure I Kaplan-Meier time to event analyses of $(\mathbf{A})$ overall survival and $(\mathbf{B})$ time to progression in patients with $\mathrm{Hb}^{\mathrm{b}}$-initiation levels $\leqslant 10 \mathrm{~g} \mathrm{dl}^{-1}$.

\section{DISCUSSION}

\section{Impact of baseline $\mathrm{Hb}$ level}

We reported previously that in an unstratified overall analysis, patients in the epoetin- $\beta$ group had a numerically, but statistically non-significant increased risk of mortality compared with patients in the control group (Aapro et al, 2008a). These results are consistent both with those of a recently published, individual patient data-based meta-analysis by the Cochrane Collaboration (Bohlius et al, 2009), which showed no negative effect of epoetin therapy in patients receiving chemotherapy, and with those from a subset of patients receiving chemotherapy in a meta-analysis published by Tonelli et al (2009). In contrast to our results, however, in the overall study population of the meta-analysis published by the Cochrane Collaboration, which included patients not receiving chemotherapy, a detrimental effect on overall survival was observed.

When stratified by baseline $\mathrm{Hb}$ level, no significantly increased negative effects on mortality were seen for the epoetin- $\beta$ group up to a baseline $\mathrm{Hb}$ level of $11 \mathrm{~g} \mathrm{dl}^{-1}$. Above this baseline $\mathrm{Hb}$ level, the risk of mortality increased for epoetin- $\beta$ patients compared with control patients. The robustness of these findings was confirmed in the pooled analyses of four studies, which collected long-term follow-up survival data (1227 patients) in which an increased risk of mortality was only seen in the subgroup of patients initiating epoetin- $\beta$ therapy with a baseline $\mathrm{Hb}>11 \mathrm{~g} \mathrm{dl}^{-1}$.

These results support the current labelling for epoetin- $\beta$, which recommends a $\mathrm{Hb}$-initiation level of $\leqslant 10 \mathrm{~g} \mathrm{dl}^{-1}$ and the updated EORTC treatment guidelines (Bokemeyer et al, 2007; Aapro and Link, 2008), which recommend a Hb-initiation level of $\leqslant 11 \mathrm{~g} \mathrm{dl}^{-1}$.

Comparable results have been reported by the Cochrane Group from an aggregated study data-based meta-analysis of ESA studies (Bohlius et al, 2006), where no significantly increased risk of mortality was seen between the ESA and control groups in those studies, which enrolled patients with baseline $\mathrm{Hb}$ levels $<10 \mathrm{~g} \mathrm{dl}^{-1}$ or in studies enrolling patients with baseline $\mathrm{Hb}$ levels $10-12 \mathrm{~g} \mathrm{dl}^{-1}$. However, in studies enrolling patients with baseline $\mathrm{Hb}$ levels above this level (7 trials; 1696 patients) an increased risk of death was seen in the ESA group.

A favourable outcome with respect to disease progression with ESAs vs control was previously shown by the Cochrane Collaboration (Bohlius et al, 2006), and in a systematic review of 46 ESA trials conducted for the National Institute for Clinical Excellence (NICE) (Wilson et al, 2007). Consistent with these findings, in this analysis, epoetin- $\beta$ treatment showed a reduced risk of disease progression both in the overall unstratified analysis and when restricted to three studies with long-term follow up for disease progression $(N=884)$. Analyses of the overall pooled population stratified by baseline $\mathrm{Hb}$ level showed similar 
A

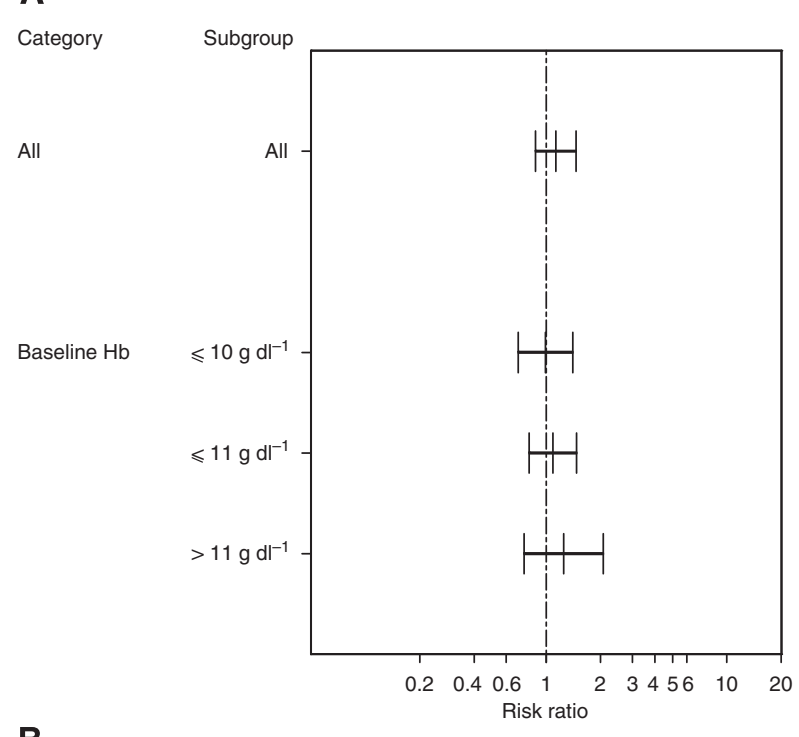

B

Category

All

C

Category

All

Subgroup

Baseline $\mathrm{Hb}$

All

(n)

Baseline $\mathrm{Hb}$

Subgroup

Baseline Ho

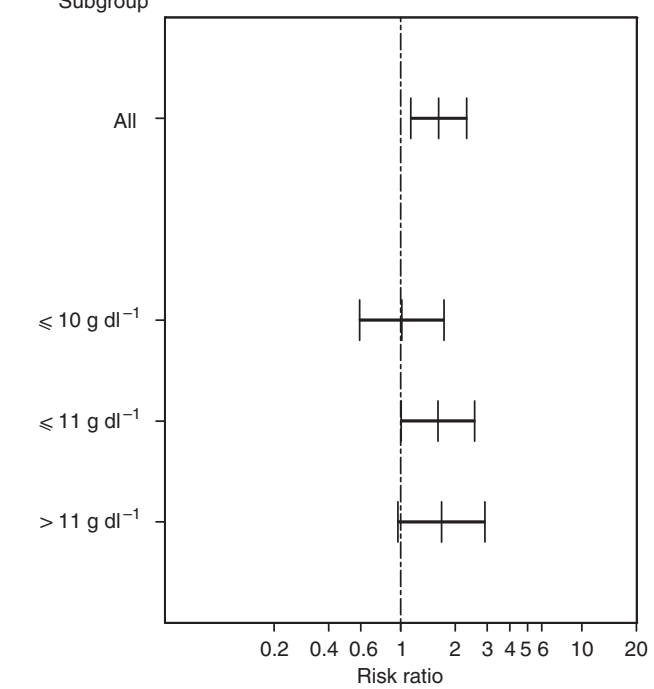

$\begin{array}{cccc}\begin{array}{c}\text { No. of } \\ \text { patients }\end{array} & \begin{array}{c}\text { Lower } \\ \text { confidence } \\ \text { limit }\end{array} & \text { Estimate } & \begin{array}{c}\text { Upper } \\ \text { confidence } \\ \text { limit }\end{array}\end{array}$

2297

0.87

$1.13 \quad 1.46$

950

$\begin{array}{lll}0.70 & 0.99 & 1.40\end{array}$

$\begin{array}{llll}1426 & 0.80 & 1.09 & 1.47\end{array}$

$\begin{array}{llll}865 & 0.75 & 1.25 & 2.07\end{array}$

$\begin{array}{cc}\text { Lower } & \text { Upper } \\ \text { No. of } & \text { confidence }\end{array}$ patients limit Estimate $\begin{gathered}\text { limit } \\ \text { lition }\end{gathered}$

$\begin{array}{llll}2297 & 0.72 & 0.85 & 1.01\end{array}$

$\begin{array}{llll}950 & 0.57 & 0.73 & 0.94\end{array}$

$\begin{array}{llll}1426 & 0.65 & 0.80 & 0.99\end{array}$

$\begin{array}{llll}865 & 0.70 & 0.95 & 1.28\end{array}$

$\begin{array}{lll}1.13 & 1.62 & 2.31\end{array}$

$\begin{array}{llll}950 & 0.59 & 1.01 & 1.73\end{array}$

$\begin{array}{llll}1426 & 1.00 & 1.60 & 2.55\end{array}$

$\begin{array}{llll}865 & 0.96 & 1.68 & 2.91\end{array}$

Figure 2 Subgroup analysis of hazard ratios for $(\mathbf{A})$ overall survival, $(\mathbf{B})$ time to progression and $(\mathbf{C})$ time to TEE by Hb-initiation level. 
Table 3 Hazard ratios for overall survival, time to progression and TEE by Hb-initiation level or maximum-achieved Hb level in long-term follow-up studies

\begin{tabular}{|c|c|c|c|c|c|c|}
\hline \multirow[b]{2}{*}{$\begin{array}{l}\text { Patient subgroup } \\
\text { Hb-initiation level }\end{array}$} & \multicolumn{3}{|c|}{ Overall survival } & \multicolumn{3}{|c|}{ Time to progression } \\
\hline & $\begin{array}{l}\text { Number } \\
\text { of patients }\end{array}$ & $\begin{array}{l}\text { Hazard ratio } \\
(95 \% \mathrm{Cl})\end{array}$ & $P$-value ${ }^{\text {a }}$ & $\begin{array}{c}\text { Number } \\
\text { of patients }\end{array}$ & $\begin{array}{c}\text { Hazard ratio } \\
(95 \% \mathrm{Cl})\end{array}$ & $P$-value ${ }^{\text {a }}$ \\
\hline \multicolumn{7}{|c|}{ Long-term follow-up studies } \\
\hline All patients & 1227 & $1.13(0.98 ; 1.31)$ & 0.082 & 884 & $1.13(0.95 ; 1.34)$ & 0.165 \\
\hline$\leqslant 10 \mathrm{gdl}^{-1}$ & 393 & $0.91(0.72 ; 1.16)$ & & 114 & $0.59(0.36 ; 0.96)$ & \\
\hline$\leqslant|| g d^{-1}$ & 612 & $1.03(0.85 ; 1.25)$ & & 285 & $0.85(0.64 ; 1.13)$ & \\
\hline$>|| g_{\mathrm{g} d l^{-1}}$ & 611 & $1.24(1.00 ; 1.53)$ & & 595 & $1.30(1.05 ; 1.61)$ & \\
\hline \multicolumn{7}{|l|}{ Maximum $\mathrm{Hb}$ value } \\
\hline \multicolumn{7}{|c|}{ Long-term follow-up studies } \\
\hline All patients & 1227 & $1.13(0.98 ; 1.31)$ & 0.082 & 884 & $1.13(0.95 ; 1.34)$ & 0.165 \\
\hline$<\log \mathrm{gll}^{-1}$ & 64 & I.7। (0.97; 3.02) & & 16 & $10.17(0.99 ; 104.36)$ & \\
\hline $10-<\left.|| g_{g}\right|^{-1}$ & 163 & $2.09(1.42 ; 3.08)$ & & 60 & $2.37(1.01 ; 5.57)$ & \\
\hline $1 \mid-<12 \mathrm{gdl}^{-1}$ & 352 & $1.89(1.45 ; 2.46)$ & & 166 & $1.85(1.14 ; 2.98)$ & \\
\hline $12-13 g d^{-1}$ & 259 & $1.59(1.15 ; 2.23)$ & & 191 & $1.75(1.13 ; 2.69)$ & \\
\hline$>13 \mathrm{gdl}^{-1}$ & 599 & $1.50(1.16 ; 1.94)$ & & 511 & $1.83(1.39 ; 2.41)$ & \\
\hline
\end{tabular}

aHR P-value (Wald test).

favourable effects of epoetin- $\beta$ vs control on disease progression in subgroups with a baseline $\mathrm{Hb}$ level of $\leqslant 10 \mathrm{~g} \mathrm{dl}^{-1}$, thus supporting the current label, and subgroups with a baseline $\mathrm{Hb}$ level $\leqslant 11 \mathrm{~g} \mathrm{dl}^{-1}$, consistent with current EORTC guidelines (Aapro and Link, 2008). In the stratified pooled analyses of the long-term follow-up studies, the favourable effect on disease progression was maintained for all subgroups, including those with baseline $\mathrm{Hb}$ levels $>11 \mathrm{~g} \mathrm{dl}^{-1}$. These results suggest, therefore, that when epoetin- $\beta$ therapy is used according to its current label and following the updated EORTC guidelines there is no increased risk of disease progression $v s$ control.

\section{Impact of maximum-achieved $\mathrm{Hb}$ level}

The increased mortality associated with erythropoietin treatment in cancer patients reported by Henke et al (2003); Leyland-Jones et al (2005), and more recently in studies by Overgaard et al (2007); Wright et al (2007); Smith et al (2008), is not supported by the present meta-analysis. Subgroup analyses based on maximumachieved $\mathrm{Hb}$ level during epoetin- $\beta$ treatment do not provide evidence for an increased risk of mortality, disease progression or TEEs with epoetin- $\beta$ compared with control in patients achieving $\mathrm{Hb}$ levels $>13 \mathrm{~g} \mathrm{dl}^{-1}$, although we observe a shift in the hazard ratios towards an increased risk for all three events associated with maximum-achieved $\mathrm{Hb}$ values between 10 and $13 \mathrm{~g} \mathrm{dl}^{-1}$.

The results of these analyses need to be interpreted with caution because of the associated methodological limitations and potential confounding influence of factors such as baseline disease status, that are related to outcome and have a strong influence on the likelihood of achieving a better response to treatment in terms of $\mathrm{Hb}$ increase. Furthermore, the comparisons undertaken here were not based on randomized groups and hence comparisons in each of the subgroups are limited by the lack of a respective control. For example, for the subgroup of patients with maximum-achieved $\mathrm{Hb}$ levels $<10 \mathrm{~g} \mathrm{dl}^{-1}$, comparisons are made between patients receiving epoetin- $\beta$ who, despite treatment, did not respond to therapy and patients in the control group who remained below $10 \mathrm{~g} \mathrm{dl}^{-1}$ without treatment. In contrast, in the subgroup of patients with maximum-achieved $\mathrm{Hb}$ levels $>13 \mathrm{~g} \mathrm{dl}^{-1}$, the comparison is between those patients who were titrated to beyond $13 \mathrm{~g} \mathrm{dl}^{-1}$ with epoetin- $\beta$ therapy and those who either achieved Hb levels above $13 \mathrm{~g} \mathrm{dl}^{-1}$ without treatment or who were enrolled with baseline $\mathrm{Hb}$ levels above $13 \mathrm{~g} \mathrm{dl}^{-1}$. On the assumption that an increase in $\mathrm{Hb}$ levels independent of epoetin- $\beta$ treatment is a good prognostic factor, these analyses would therefore be biased in favour of the control group. Nonetheless, no convincing evidence was found in the present analyses to suggest that high $\mathrm{Hb}$ values achieved with epoetin- $\beta$ therapy are associated with an increased risk of death, disease progression or TEEs.

\section{Risk factors for thromboembolic events}

The present analyses show a significantly increased TEE rate with epoetin- $\beta$ compared with control ( 0.22 events/patient year $v s 0.14$ events/patient year) and an increased risk of thromboembolic events with epoetin- $\beta$. These results are consistent with those reported in both meta-analyses of the Cochrane Collaboration (Bohlius et al, 2005, 2006). Subgroup analyses based on $\mathrm{Hb}$ initiation level indicate a correlation between $\mathrm{Hb}$-initiation level and risk of TEE. This increased TEE risk is well documented within the ESA class in general and adequately addressed in the product labelling for all approved ESAs.

Among the multiple risk factors shown for thromboembolic disease, the most influential include increasing age, prolonged immobility, malignant disease, major surgery, multiple trauma, previous venous thromboembolism and chronic heart failure (Anderson and Spencer, 2003). Increased TEE risk has been suggested to be related not only to the presence of these individual risk factors, but also to the number of pre-disposing risk factors at baseline (Nicolaides and Irving 1975; Wheeler et al, 1982). In the present analysis five major pre-disposing risk factors for TEEs in patients receiving epoetin- $\beta$ therapy were identified (age $>65$ years, previous thromboembolic event, coronary artery disease, hypertension and dyslipidemia). Furthermore, the combination of two or more of these risk factors in epoetin- $\beta$-treated patients markedly increased the risk of a TEE. Recently, an association between RBC and platelet transfusions and an increased risk of TEEs and mortality in cancer patients has also been suggested (Khorana et al, 2008). Further investigation of this potential causal relationship in patients included in the epoetin- $\beta$ studies is merited.

The results could suggest a potential role for the use of prophylactic antithrombotic agents in patients with known risk factors who are scheduled to receive epoetin- $\beta$ therapy (Aapro et al, 2009). Further investigation is required to confirm the benefits of such treatment in combination with epoetin- $\beta$. These results concerning the increased risk for TEEs with epoetin- $\beta$ are consistent with the observation and conclusions of the Cochrane meta-analyses (Bohlius et al, 2005, 2006) and are currently addressed in the labelling recommendations for epoetin- $\beta$. 
A

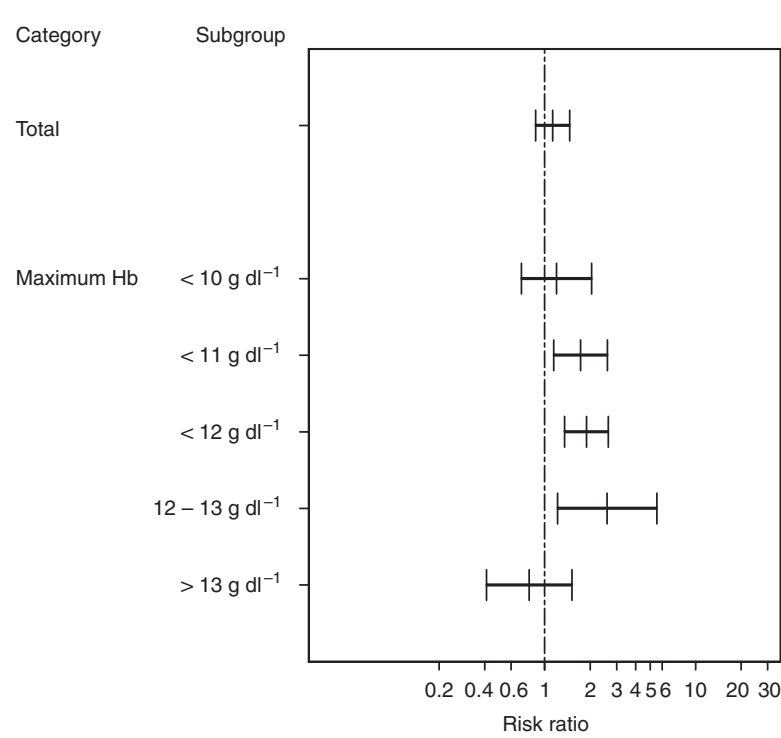

B

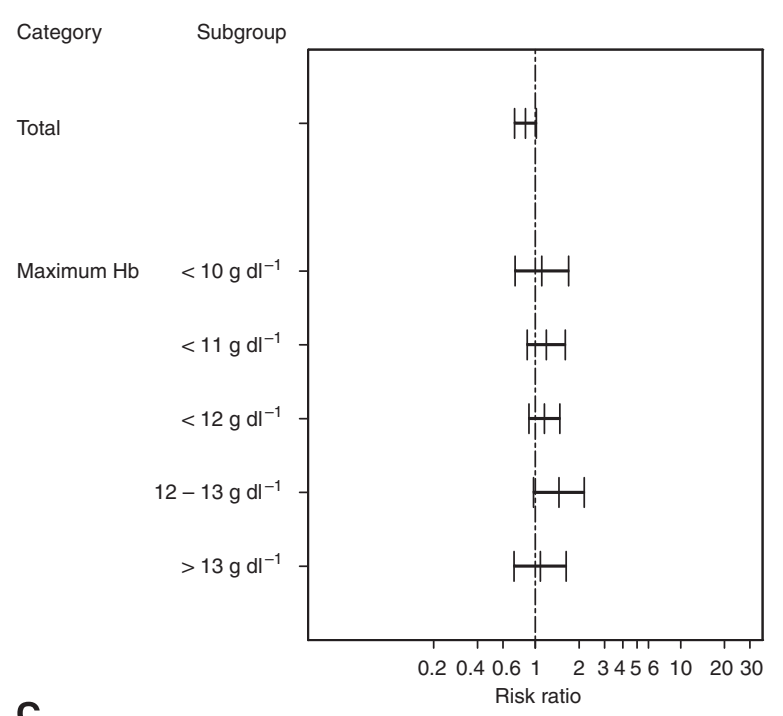

C

Category

Total

Maximum Hb
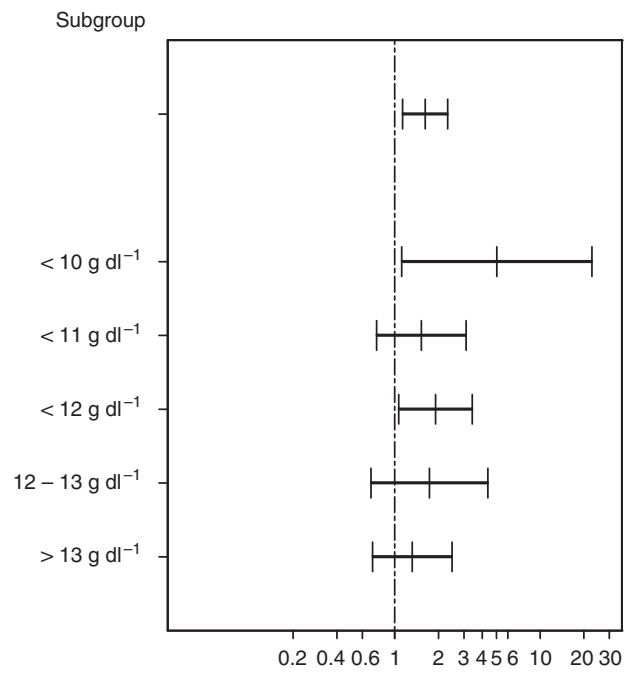

Risk ratio

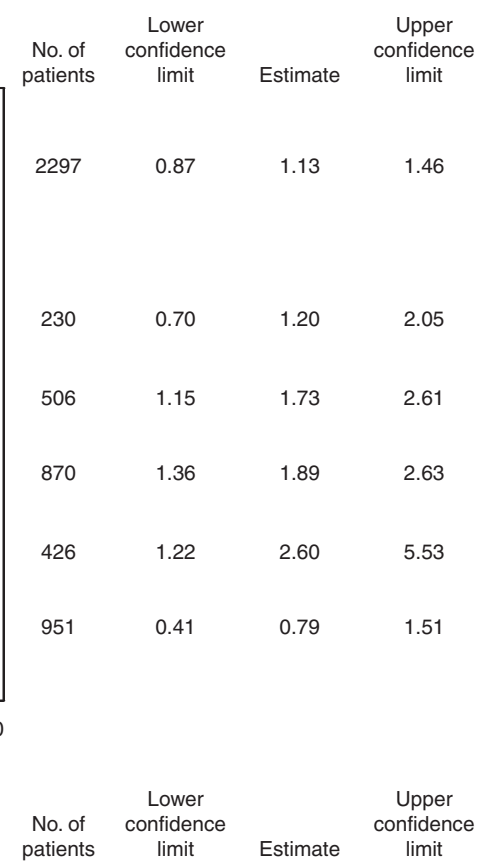

$\begin{array}{llll}2297 & 0.72 & 0.85 & 1.01\end{array}$

$\begin{array}{llll}230 & 0.73 & 1.11 & 1.69\end{array}$

$\begin{array}{llll}506 & 0.88 & 1.19 & 1.61\end{array}$

$\begin{array}{llll}870 & 0.90 & 1.15 & 1.47\end{array}$

$\begin{array}{llll}426 & 0.97 & 1.45 & 2.17\end{array}$

$\begin{array}{llll}951 & 0.71 & 1.08 & 1.63\end{array}$

No. of confidence $\quad \begin{gathered}\text { Upper } \\ \text { confidence }\end{gathered}$

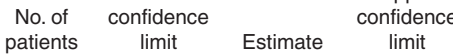

$\begin{array}{llll}2297 & 1.13 & 1.62 & 2.31\end{array}$

$\begin{array}{llll}230 & 1.12 & 5.04 & 22.73\end{array}$

$\begin{array}{llll}506 & 0.75 & 1.53 & 3.10\end{array}$

$\begin{array}{llll}870 & 1.07 & 1.91 & 3.42\end{array}$

$\begin{array}{llll}426 & 0.69 & 1.73 & 4.37\end{array}$

$\begin{array}{llll}951 & 0.70 & 1.32 & 2.48\end{array}$

Figure 3 Subgroup analysis of hazard ratios for $(\mathbf{A})$ overall survival, $(\mathbf{B})$ time to progression and $(\mathbf{C})$ time to TEE by maximum-achieved Hb level. 
Table 4 Risk analysis for time to thromboembolic event

\begin{tabular}{|c|c|c|c|c|c|c|c|c|}
\hline Covariate & $n$ & \multicolumn{3}{|c|}{ Covariate factor effect } & \multicolumn{4}{|c|}{ Treatment effect adjusted by covariate } \\
\hline Age $>65$ years at baseline & \multicolumn{3}{|c|}{ Control } & & Epoetin- $\beta$ & & & \\
\hline
\end{tabular}

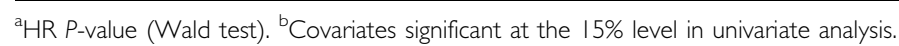

\section{CONCLUSIONS}

This individual patient data-based meta-analysis of 12 controlled epoetin- $\beta$ studies in cancer patients is the first to enable subgroup analyses assessing the risk of ESA therapy associated with different $\mathrm{Hb}$-initiation levels. Results indicate that when used within the terms of its licensed indication (i.e., Hb-initiation level $\leqslant 10 \mathrm{~g} \mathrm{dl}^{-1}$ ) or within the updated EORTC guidelines (i.e., Hb-initiation level $\leqslant 11 \mathrm{~g} \mathrm{dl}^{-1}$ ), there was no evidence of an increased risk of mortality or disease progression associated with epoetin- $\beta$ therapy. Consistent with other published meta-analyses, the thromboembolic event rate was significantly increased. The number and combination of pre-disposing risk factors for TEEs at baseline should be taken into account before initiating epoetin- $\beta$ therapy, and potential preventative measures should be considered. Although there is a clear trend towards a higher risk of overall mortality, disease progression and thromboembolic event rate was observed with increasing baseline $\mathrm{Hb}$ values, such a trend was not seen in patients who achieved higher $\mathrm{Hb}$ values, especially when $\mathrm{Hb}$ values above $13 \mathrm{~g} \mathrm{dl}^{-1}$ were exceeded during therapy.

\section{REFERENCES}

Aapro M, Scherhag A, Burger HU (2008a) Effect of treatment with epoetin beta on survival, tumour progression and thromboembolic events in patients with metastatic cancer: an updated meta-analysis of 12 randomized controlled studies including 2301 patients. $\mathrm{Br} \mathrm{J}$ Cancer 99(1): $14-22$

Aapro M, Leonard RC, Barnadas A, Marangolo M, Untch M, Malamos N, Mayordomo J, Reichert D, Pedrini JL, Ukarma L, Scherhag A, Burger $\mathrm{H}-\mathrm{U}$ (2008b) Effect of once weekly epoetin beta on survival in patients with metastatic breast cancer receiving anthracycline- and/or taxane-based chemotherapy - results of the BRAVE study. J Clin Oncol 26: 592-598

Aapro M, Barnadas A, Leonard RC, Marangolo M, Untch M, Ukarma L, Burger H-U, Scherhag A, Osterwalder B (2009) What is the impact of antithrombotic therapy and risk factors on the frequency of thrombo-vascular events in patients with metastatic breast cancer receiving epoetin beta? Eur J Cancer, epub ahead of print, 29 July 2009, doi:10.1016/j.ejca.2009.06.31

Aapro M, Link H (2008) September 2007 Update on EORTC guidelines and anemia management with erythropoiesis-stimulating agents. The Oncologist 13(suppl 3): 33-36

Acs G, Acs P, Beckwith SM, Pitts RL, Clements E, Wong K, Verma A (2001) Erythropoietin and erythropietin receptor expression in human cancer. Cancer Res 61: $3561-3565$

Acs G, Zhang PJ, Rebbeck TR, Acs P, Verma A (2002) Immunohistochemical expression of erythropoietin and erythropoietin receptor in breast carcinoma. Cancer 95(5): 969-981
Anderson FA, Spencer FA (2003) Risk factors for venous thromboembolism. Circulation 107: I-9-I-16

Antonadou D, Cardamakis E, Puglisi M (2001) Erythropoietin enhances radiation treatment efficacy in patients with pelvic malignancies: final results of a randomized phase III study. Eur J Cancer 37(Suppl 6): A530

Arcasoy MO, Amin K, Karayal AF, Chou SC, Raleigh JA, Varia MA, Haroon ZA (2002) Functional significance of erythropoietin receptor expression in breast cancer. Lab Invest 82(7): $911-918$

Besarab A, Bolton WK, Browne JK, Egrie JC, Nissenson AR, Okamoto DM, Schwab SJ, Goodkin DA (1998) The effects of normal as compared with low haematocrit values in patients with cardiac disease who are receiving hemodialysis and epoetin. N Engl J Med 339: 584-590

Bokemeyer C, Oechsle K, Hartmann J-T (2005) Anaemia in cancer patients: pathophysiology, incidence and treatment. Eur J Clin Invest 35(Suppl 3): $26-31$

Bokemeyer C, Aapro MS, Courdi A, Foubert J, Link H, Österborg A, Repetto L, Soubeyran P, European Organization for research and Treatment of Cancer (EORTC) Taskforce for the Elderly (2007) EORTC guidelines for the use of erythropoietic proteins in anaemic patients with cancer: 2006 update. Eur J Cancer 43: 258-270

Bohlius J, Langensiepen S, Schwarzer G, Seidenfeld J, Piper M, Bennett C, Engert A (2005) Recombinant human erythropoietin and overall survival in cancer patients: results of a comprehensive meta-analysis. J Natl Cancer Inst 97: 489-498 
Bohlius J, Wilson J, Seidenfeld S, Piper M, Schwarzer G, Sandercock J, Trelle S, Weingart O, Bayliss S, Djulbegovic B, Bennet CL, Langensiepen S, Hyde C, Engert A (2006) Erythropoietin or darbepoetin for patients with cancer. Cochrane Database of Systematic Reviews Article no.: CD003407. DOI: 10.1002/14651858.CD003407.pub4

Bohlius J, Brillant C, Clarke M, Kluge S, Napoli M, Piper M, Rades D, Schumacher M, Schmidlin K, Schwarzer G, Seidenfeld J, Steensma DP, Trelle S, Weingart O, Zwahlen M, Egger M, Engert A (2008) Recombinant human erythropoiesis stimulating agents in cancer patients: individual patient data meta-analysis on behalf of the EPO IPD Meta-analysis Collaborative Group. Blood 112: 4675

Bohlius J, Schmidlin K, Brillant C, Schwarzer G, Trelle S, Seidenfeld J, Zwahlen M, Clarke M, Weingart O, Kluge S, Piper M, Rades D, Steensma DP, Djulbegovic B, Fey MF, Ray-Coquard I, Machtay M, Moebus V, Thomas G, Untch M, Schumacher M, Egger M, Engert A (2009) Recombinant human erythropoiesis-stimulating agents and mortality in patients with cancer: a meta-analysis of randomised trials. Lancet 373: $1532-1542$

Boogaerts M, Coiffier B, Kainz C, Epoetin Beta QOL Working Group (2003) Impact of epoetin beta on quality of life in patients with malignant disease. Br J Cancer 88: 988-995

Caro JJ, Salas M, Ward A, Goss G (2001) Anemia as an independent prognostic factor for survival in patients with cancer: a systematic, quantitative review. Cancer 91: 2214-2221

Cazzola M, Messinger D, Battistel V, Bron D, Cimino R, Enller-Ziegier L, Essers U, Greil R, Grossi A, Jager G, Le Mevel A, Najman A, Silingardi V, Spriano M, van Hoof A, Ehmer B (1995) Recombinant human erythropoietin in the anaemia associated with multiple myeloma or non-Hodgkin's lymphoma: dose finding and identification of predictors of response. Blood 86: $4446-4453$

Crawford J, Cella D, Cleeland CS, Cremieux PY, Demetri GD, Sarokhan BJ, Slavin MB, Glaspy JA (2002) Relationship between changes in hemoglobin level and quality of life during chemotherapy in anemic cancer patients receiving epoetin alfa therapy. Cancer 95: 888-895

Glaser CM, Millesi W, Kornek GV, Long S, Schull B, Watzinger F, Selzer E, Lavey RS (2001) Impact of hemoglobin level and use of recombinant erythropoietin on efficacy of preoperative chemoradiation therapy for squamous cell carcinoma of the oral cavity and oropharynx. Int J Radiat Oncol Biol Phys 50: 705-715

Henke M, Laszig R, Rube C, Schafer U, Hasse KD, Schilcher B, Mose S, Beer KT, Burger U, Dougherty C, Frommhold H (2003) Erythropoietin to treat head and neck cancer patients with anaemia undergoing radiotherapy: randomised, double-blind, placebo-controlled, trial. Lancet 362: $1255-1260$

Janecka IP (2004) Letter. Lancet 363: 992

Kelleher DK, Thews O, Vaupel P (1998) Can Erythropoietin Improve Tumor Oxygenation? Strahlentherapie und Onkologie 174(Suppl IV): 20-23

Kettelhack C, Hones C, Messinger D, Schlag PM (1998) Randomized multicenter trial of the influence of recombinant human erythropoietin on intraoperative and postoperative transfusion need in anaemic patients undergoing right hemicolectomy for carcinoma. Br J Surg 85: 63-67

Khorana AA, Francis CW, Blumberg N, Culakova E, Refaai MA, Lyman GH (2008) Blood transfusions, thrombosis, and mortality in hospitalized patients with cancer. Arch Intern Med 168(21): 2377-2381

Leyland-Jones B, Mahmud S (2004) Erythropoietin to treat anaemia in patients with head and neck cancer [letter]. Lancet 363: 80

Leyland-Jones B, Semiglazov V, Pawlicki M, Pienkowski T, Tjulandi S, Makhson A, Roth A, Dodwell D, Basalga J, Biakhov M, Valuckas K, Voznui E, Lui X, Vercammen E (2005) Maintaining normal hemoglobin levels with epoetin alfa in mainly non-anaemic patients with metastatic breast cancer receiving first-line chemotherapy: a survival study. J Clin Oncol 23: $5960-5972$

Littlewood TJ, Bajetta E, Nortier JW, Vercammen E, Rapaport B, Epoetin Alfa Study Group (2001) Effects of epoetin alfa on hematologic parameters and quality of life in cancer patients receiving nonplatinum chemotherapy: results of a randomized, double-blind, placebo-controlled clinical trial. J Clin Oncol 19: 2865-2874

Ludwig H, van Belle S, Barrett-Lee P, Birgegard G, Bokemeyer C, Gascon P, Kosmidis P, Krzakowski M, Nortier J, Olmi P, Schneider M, Schrijvers D (2004) The European Cancer Anemia Survey (ECAS): A large, multinational, prospective survey defining the prevalence, incidence, and treatment of anemia in cancer patients. Eur J Cancer 40: 2293-2306

Luksenburg H, Weir A, Wager R (2004) FDA Briefing Document: Safety Concerns Associated with Aranesp (darbepoetin alfa) Amgen, Inc. and Procrit (epoetin alfa) Ortho Biotech, L.P., for the Treatment of Anemia
Associated with Cancer Chemotherapy, http://www.fda.gov/ohrms/ dockets/ac/cder04.html\#oncologic, accessed 15 September 2009

Mittelman M, Neumann D, Peled A, Kanter P, Haren-Ghera N (2001) Erythropoietin induces tumour progression and antitumour immune responses in murine myeloma models. Proc Natl Acad Sci USA 98: $5181-5186$

Nicolaides AN, Irving D (1975) Clinical factors and the risk of deep venous thrombosis. In Thromboembolism Etiology Advances in Prevention and Management Nicolaides A (ed) 193-204. University Park Press: Baltimore, MD

Oberhoff C, Neri B, Amadori D, Petry KU, Gamucci T, Rebmann U, Nowrousian MR, Voigtmann R, Monfardini S, Armand JP, Herrman R, Netter-Pinon J, Tubiana-Mathiew N, Zwierzina H (1998) Recombinant human erythropoietin in the treatment of chemotherapy-induced anemia and prevention of transfusion requirement associated with solid tumors: a randomized, controlled study. Ann Oncol 9: 255-260

Österborg A, Brandberg Y, Molostova V, Iosava G, Abdulkdyrov K, Hedenus M, Messinger D, Epoetin Beta Hematology Study Group (2002) Randomized, double-blind, placebo-controlled trial of recombinant human erythropoietin, epoetin beta, in hematologic malignancies. J Clin Oncol 20: 2486-2494

Österborg A, Boogaerts MA, Cimino R, Essers U, Holowiecki J, Juliusson G, Jager G, Najmen A, Peest D (1996) Recombinant human erythropoietin in transfusion-dependent anaemic patients with multiple myeloma and non-Hodgkin's lymphoma - a randomized multicenter study. Blood 87: $2675-2682$

Österborg A, Brandberg Y, Hedenus M (2005) Impact of epoetin-beta on survival of patients with lymphoproliferative malignancies: a long-term follow up of a large randomized study. Br J Haematol 129: 206-209

Overgaard J, Hoff C, Sand Hansen H, Specht L, Overgaard M, Grau C, Andersen E, Johansen J, Andersen L, Evensen J (2007) Randomized study of the importance of novel erythropoiesis stimulating protein (Aranesp) for the effect of radiotherapy in patients with primary squamous cell carcinoma of the head and neck (HNSCC) - the Danish Head and Neck Cancer Group DAHANCA 10. Eur J Cancer Supplements 5(6): 7

Rau B, Schlag PM, Willeke F, Herforth C, Stephen P, Frake W (1998) Increased autologous blood donation in rectal cancer by recombinant human erythropoietin (rhEPO). Eur J Cancer 34: 992 - 998

Smith Jr RE, Aapro MS, Ludwig H, Pintér T, Smakal M, Ciuleanu TE, Chen L, Lillie T, Glaspy JA (2008) Darbepoetin alpha for the treatment of anemia in patients with active cancer not receiving chemotherapy or radiotherapy: results of a phase III, multicenter, randomized, doubleblind, placebo-controlled study. J Clin Oncol 26(7): 1040-1050

Strauss HG, Haensgen G, Dunst J, Hayward CR, Burger HU, Scherhag A, Koelbl H (2008) Effects of anemia correction with epoetin beta in patients receiving radiochemotherapy for advanced cervical cancer. Int $J$ Gynecol Cancer 18(3): 515-524

Stuben G, Pottgen C, Knuhmann K, Schmidt K, Stusche M, Thews O, Vaupel P (2003) Erythropoietin restores the anemia-induced reduction in radiosensitivity of experimental human tumors in nude mice. Int $J$ radiat Oncol Biol Phy 55: 1358-1362

ten Bokkel Huinink WW, de Swart CA, van Toorn DW, Morack G, Breed WP, Hillen HF, van der Haeven JJ, Reeds NS, Fairlamb DJ, Chan SY, Godfrey KA, Kristenson GB, van Tinteren H, Ehmer B (1998) Controlled, multicentre study of the influence of subcutaneous recombinant human erythropoietin on anaemia and transfusion dependency in patients with ovarian carcinoma treated with platinum-based chemotherapy. Med Oncol 15: $174-182$

Thews O, Kelleher DK, Vaupel P (2001) Erythropoietin restores the anemiainduced reduction in cyclophosphamide cytotoxicity in rat tumors. Cancer Res 61: 1358-1361

Tonelli M, Hemmelgarn B, Reiman T, Manns B, Reaume MN, Lloyd A, Wiebe N, Klarenbach S (2009) Benefits and harms of erythropoiesisstimulating agents for anemia related to cancer: a meta-analysis. $C M A J$ 180(11): E62 -E71. DOI:10.1503/cmaj.090470

Vansteenkiste J, Pirker R, Massuti B, Barata F, Font A, Fiegl M, Siena S, Gatkey J, Tomita D, Colowick AB, Musil J, Aranesp 980297 Study Group (2002) Double-blind, placebo-controlled, randomized phase III trial of darbepoetin alfa in lung cancer patients receiving chemotherapy. J Natl Cancer Inst 94: 1211 - 1220

Vaupel P, Mayer A (2004) Erythropoietin to treat anaemia in patients with head and neck cancer [letter]. Lancet 363: 992

Wheeler HB, Anderson FA, Cardullo PA, Patwardhan NA, Jian-Ming L, Cutler BS (1982) Suspected deep vein thrombosis. Management by impedance plethysmography. Arch Surg 117(9): 1206-1209 
Wilson J, Yao GL, Raftery J, Bohlius J, Brunskill S, Sandercock J, Bayliss S, Moss P, Stanworth S, Hyde C (2007) A systematic review and economic evaluation of epoetin alpha, epoetin beta and darbepoetin alpha in anaemia associated with cancer, especially that attributable to cancer treatment. Health Technol Assess 11: 1-202

Wright JR, Ung YC, Julian JA, Pritchard KI, Whelan TJ, Smith C, Szechtman B, Roa W, Mulroy L, Rudinskas L, Gagnon B, Okawara GS,
Levine MN (2007) Randomized, double-blind, placebo-controlled trial of erythropoietin in non-small-cell lung cancer with disease-related anemia. J Clin Oncol 25(9): 1021-1023

Yasuda Y, Fujita Y, Matsuo T, Koinuma S, Hara S, Tazaki A, Onozaki M, Hashimoto M, Musha T, Ogawa K, Fujita H, Nakamura Y, Shiozaki H, Utsumi H (2003) Erythropoietin regulates tumour growth of human malignancies. Carcinogenesis 24: 1021-1029 